\title{
A Collaborative Community Education Model: Developing Effective School-Community Partnerships
}

\author{
Thea DePetris ${ }^{1}$ \& Chris Eames ${ }^{2}$ \\ ${ }^{1}$ Kids Greening Taupō, New Zealand \\ ${ }^{2}$ Faculty of Education, University of Waikato, New Zealand
}

\begin{abstract}
Despite school-community partnerships having much potential to provide educational organisations with authentic teaching and learning opportunities through community-based action projects, they remain under-utilised largely due to the structural constraints and pressures faced by teachers. This study helps fill a gap in scholarly discourse about the specific ways in which school-community partnerships can effectively be developed by providing an in-depth account of an 18-month pilot project with the aim to develop a conservation education program (Kids Greening Taupō) through a partnership structure in Aotearoa New Zealand. An evaluation of the pilot project was conducted using an ethnographic approach, which sought stakeholder perspectives about the program's developmental process through an interpretive lens. Qualitative data were collected through participant observation, semi-structured interviews and document analysis, and then thematically analysed. The findings provided in this article illuminate stakeholder insights and perspectives about the structures established and processes utilised over the three broad stages of program planning, implementation and maintenance, and the resultant environmental initiatives and programs. Through this study, a Collaborative Community Education Model has emerged that may serve as a potential framework or starting point for those interested in creating a new schoolcommunity partnership or to modify an existing one.
\end{abstract}

\begin{abstract}
School-community partnerships are a potential mechanism for helping educational organisations engage with their respective wider communities and develop meaningful and ongoing relationships. Given adequate time and support, such partnerships can assist educators to develop and deliver authentic learning opportunities based on current local issues and problems. Furthermore, through school community partnerships, resources, expertise, leadership, and networking between cross-sectoral bodies may be rationalised and distributed to grassroot efforts involving children and young people as agents of change. Ideally, such partnerships lead to a mutually beneficial program enabling all stakeholders to work towards achieving a shared vision or goal to
\end{abstract}

Address for correspondence: Thea DePetris, Kids Greening Taupō, New Zealand. Email: theadepet@hotmail.com 
resolve a local issue, while simultaneously achieving their respective organisational objectives. However, although such partnerships offer many educational, social, and environmental benefits (Davies \& Johnson, 1996; Epstein \& Sanders, 1998; Hands, 2005), historically, they have been under-utilised because of a wide range of impeding barriers and challenges (Barza, 2013; Bolstad, 2015; Ernst, 2007; Israel, Schulz, Parker, \& Becker, 2001). At present, there is little academic literature through which authors specifically provide guidance about developing and maintaining school community partnerships, particularly those that engage children and young people in community-based action projects (Bolstad, 2015; Hands, 2005; Sanders, 2001). To help address this knowledge gap, an evaluation was conducted of an 18-month pilot project to design and implement the conservation education program, Kids Greening Taupō, through the formation of a school community partnership in Aotearoa New Zealand (DePetris, 2016).

We begin with a description of the origin of Kids Greening Taupō, followed by an overview of the theoretical framework and methodology of this study. Next, the findings from the evaluation are presented, starting with a short description of the authentic educational opportunities provided by Kids Greening Taupō, as this will help readers to more fully appreciate the stakeholders' perspectives. Thereafter, the summary of findings presented highlight the educational opportunities the stakeholders perceived were generated through the program and the significant enablers and barriers related to the development of the program through a partnership structure. Lastly, the Collaborative Community Education Model that emerged from this research is discussed in conjunction with the partnership literature, providing readers with some key enabling elements.

\section{The Origin of Kids Greening Taupō}

In Aotearoa New Zealand, the Department of Conservation's National Education Strategy 2010-2030 describes education as the key to broadening support for conservation and the development of ecological literacy and conservation capability (Department of Conservation [DOC], 2011). In accordance with this strategy, the Department had partnered with a local non-government organisation, three schools, two early childhood centres, and local businesses to establish a conservation education program in Te Anau, a small town bordering Fiordland National Park in the South Island. The goals of this program, Kids Restore the Kepler (the Kepler program), are to empower young people, from preschool to college, to develop knowledge, explore values, and take action to restore native birdlife in the neighbouring Kepler region of the National Park (Kids Restore the Kepler, 2016).

At a later date, the Department's Outreach and Education team identified the Kepler program as a promising model that could potentially be replicated in other parts of the country. This team identified from the Kepler program four potential 'transferable' components as: (1) an authentic teaching and learning opportunity, (2) schools working together and collaborating across the wider community, (3) an ethos of 'students in the driver's seat', and (4) a continuous (cross-curriculum) learning journey.

In October 2014, an opportunity to pilot a conservation education program based on the Kepler program arose in Taupō, a provincial town of approximately 30,000 people in the North Island (Statistics New Zealand, 2016). The design of this program, Kids Greening Taupō, was kept as closely aligned to the Kepler program as possible so it could serve as a test case to determine the feasibility of developing other similar programs around the country. Like the Kepler program, Kids Greening Taupō was initiated to 
develop conservation knowledge, skills, values, and behaviour among the town's young people while achieving ecological restoration at the same time.

\section{Theoretical Perspectives: Developing Effective School Community Partnerships in Conservation Education}

A growing recognition of the changing nature of knowledge and 'wicked' problems has had implications for the role of contemporary education (Bolstad, 2015; Dator, 2014; Hill \& Brown, 2014). This has seen educational scholars promoting a paradigm shift in relation to the philosophical underpinnings of education (i.e., how people 'think' about education and what it means to be educated) and the system in which the practice is embedded (Hipkins, Cowie, Boyd, Keown, \& McGee, 2011; McDowall \& Whatman, 2016; Stirling, 2001).

Within recent literature, there has been a re-emergence of both school community partnerships and place-based education. Although not new educational phenomena, the increased reference to these approaches signals the possible merit in their use as a new norm for educational philosophy and practice. Historically, place-based education has often been integrated with other educational approaches (e.g., cultural studies, nature learning) in order to connect teachers and students with real-life local contexts (Gruenewald, 2003; Smith, 2002), while partnerships have been a focus of scholarly attention, particularly with regard to the many benefits but also challenges of involving families and the wider community with educational organisations (Hands, 2005; Epstein \& Sanders, 1998; Davies \& Johnson, 1996; Epstein, 1987). More recently, school community partnerships have been identified by some as a key component of a 21 st-century approach to education because of their potential to help teachers develop learning programs based on authentic knowledge building and action-oriented experiences in the community context (Bolstad et al., 2012; McMillan \& Binns, 2011).

The values espoused through a 'systems thinking' perspective (Falk et al., 2015) have spurred an increasing trend of partnership models and cross-sectoral collaboration across a range of sectors (Israel, Schulz, Parker, \& Becker, 1998; Margerum, 2008; Thompson, 2002). But this trend is much less prevalent in the formal education sector (Bolstad, 2015). Furthermore, partnerships developed to date tend to be philanthropic and/or extra-curricular for the sole purpose of the educator's goals rather than a genuine cross-collaborative relationship in relation to community-based action opportunities (Monroe, Ballard, Oxarart, Sturtevant, \& Evans, 2016). This study was focused on this latter type of partnership so that a mutually beneficial relationship can be formed in order to work towards achieving a shared vision, while also meeting stakeholder objectives (McMillan \& Binns, 2011; Sanders, 2001). In this sense, school community partnerships have the potential to assist educational organisations develop learning programs that are authentic and relevant, and therefore likely to lead to improved student engagement and learning outcomes (Ferreira, Grueber, \& Yarema, 2012), and ultimately transform educational organisations into social agents of change in the local context (Uzzell, 1999).

However, despite such potential, school community partnerships of genuine benefit to all stakeholders are not the norm (Monroe et al., 2016), as both educators and community partners face significant barriers and challenges to their development and maintenance. Some of the most commonly reported difficulties include a lack of a supportive school climate (Ernst, 2007) and adequate time to plan (Sanders \& Lewis, 2005), and a lack of 'in-house' resources to connect with potential partners and sustain organisational buy-in for the long term (Bolstad, 2015). 
For this study, literature about partnerships from a range of fields was reviewed in an attempt to identify key enabling elements and processes that could assist the effective formation of school community partnerships aimed at ensuring such barriers and challenges can be overcome. A broad summary of the applicable theoretical perspectives related to the development of effective partnerships is given next.

In considering social structures like partnerships, an ecological perspective is increasingly being sought to better inform their design and functioning (Orr, 1992). An ecological perspective identifies partnerships as 'a key characteristic of life', as they enable organisms to organise and maintain themselves in a sustainable way (Capra, 1994, p. 7). Through interdependence, cooperation and feedback loops among a diverse set of species, ecosystems continuously self-regulate and self-organise (Capra, 1994).

Drawing upon this depiction of sustainable ecosystem functioning, partnerships among humans may be viewed as the interdependent relationships between people and organisations that are necessary to achieve something that would otherwise be extremely difficult or impossible to achieve (Wei-Skillern \& Silver, 2013). It is through this interdependence that cooperation between stakeholders is maintained. Continuous feedback via communication within the network of relationships is vital for balancing the changes and fluctuations of a social context (Hands, 2005). In order to remain resilient, develop and evolve, a partnership should endeavour to incorporate flexibility into its structure (Hands, 2005), and as such, communication and cooperation between partners should be fostered. Failure to incorporate flexibility could result in the early demise of a partnership as a result of it becoming obsolete and irrelevant in a continually changing environment. Lastly, the element of diversity in a partnership is reflected by the composition of partners (otherwise referred to as stakeholders). Wei-Skillern and Silver (2013) argue that partner selection is of the utmost importance, as establishing the right mix of partners lays a foundation of trust-based relationships from which holistic, coordinated and realistic decisions and solutions may arise. Therefore, through this analogy, the elements of interdependence, cooperation, communication, flexibility, and diversity are identified as enabling effective and sustainable partnerships.

In terms of developing such partnerships, three broad stages were identified as planning, implementing, and maintaining, with each of these stages incorporating a number of processes that foster the enabling characteristics as described above.

\section{Step 1: Planning}

Prioritising the planning stage is paramount to developing and maintaining effective partnerships (Barza, 2013; Ministry of Education [MoE], 2015; Minkler, Vásquez, Tajik, \& Petersen, 2008; Sanders, 2001; Thompson, 2002), and it has been argued that the importance of this stage should not be underestimated (Sanders \& Lewis, 2005). Three processes within this stage include: (1) partner selection; (2) negotiation of organisational objectives and a shared vision; and (3) identification of partnership principles, including proposed operational procedures and assumptions, leadership and culture (MoE, 2015).

\section{Step 2: Implementation}

Following the planning stage, partners collectively develop action steps and delegate responsibilities necessary for working towards the shared vision and their respective objectives (MoE, 2015). During the design and implementation stage, a range of 'hurdles' are likely to arise, although the number and magnitude of these challenges can be minimised through a robust planning stage (Sanders \& Lewis, 2005). Thompson (2002) recommends that all parties be on alert to issues of power, inequality and exclusiveness, as these are obstacles that commonly crop up when implementing partnership 
activities. During times of challenges, it is the enabling elements, shared vision and partnership principles that become the 'glue' holding stakeholders together (Chapin, Mark, Mitchell, \& Dickinson, 2012; Wei-Skillern \& Silver, 2013).

\section{Step 3: Maintaining}

An effective partnership is described by Wei-Skillern and Silver (2013) as an array of equal, interconnected partners working towards a shared vision through the development of trust and ability to work-to-strengths. Such characteristics typically require long-term commitment through organisational buy-in, as time is a crucial factor that enables partnerships to evolve organically, develop wholly, and transform the ways of working for those involved (Woodhouse, 2009). Commonly, there is also the need for a committed individual to facilitate and coordinate partner involvement in order to keep all participants well informed and make the most of potential contributions from the partners. Referred to as a 'boundary-broker' by Monroe et al. (2016, p. 1105), this person should have the ability to work across organisational cultures, foresee program opportunities that satisfy multiple needs, and clearly articulate ideas across a variety of audiences (including children and young people in the case of a school community partnership). Furthermore, professional development opportunities for teachers that help schools develop their own 'in-house' expertise and resources are particularly important for educational partnerships (Monroe et al., 2016), as is an evaluative system for monitoring progress and implementing feedback (Chapin et al., 2012).

\section{Methodology}

This study involved a small-scale evaluation of the 18-month Kids Greening Taupo pilot project. Set in the interpretive paradigm, the study utilised an ethnographic approach as it sought to understand the stakeholders' and education coordinator's 'lived' experiences, and constructed meanings about the structures, processes and outcomes associated with the development of the conservation education program. Herein, 'structures' refers to the tangible elements comprised of people, resources and documentation, and 'processes' refers to the activities undertaken by stakeholders and the education coordinator.

\section{Sampling}

For this research, a purposive sampling technique was utilised through which the sample was comprised of all the Kids Greening Taupō stakeholder representatives and the education coordinator (23 participants in total). The stakeholder representatives were affiliated with five educational organisations and four community organisations. The education coordinator was an employee. This sample involved all the adults who were in one way or another involved with the development of Kids Greening Taupō through the partnership model. Because Kids Greening Taupō seeks a student-led approach to program development, ideally some students would have been part of the sample as well; however, the limited capacity of this research project prevented this inclusion.

Table 1 provides a breakdown of the sample based on the participant's affiliated organisations and potential contribution(s) as outlined in the Kids Greening Taupo strategy (Kids Greening Taupō, 2015). The participants were brought on board through direct personal communication. For example, the initial idea for the program was conceived by one of the Department of Conservation's representatives, who then approached the Greening Taupo representatives and the secondary school teacher representatives. Thereafter, this group of representatives collectively approached Tūwharetoa Māori Trust Board, Taupō District Council, and the senior management 
TABLE 1: Overview of Stakeholder Organisations and Number of Representatives Involved

\begin{tabular}{|c|c|c|}
\hline Organisation type & Contribution & $\begin{array}{l}\text { No. of } \\
\text { representatives }\end{array}$ \\
\hline $\begin{array}{r}\text { Department of } \\
\text { Conservation }\end{array}$ & $\begin{array}{l}\text { Provide ecological and conservation } \\
\text { education expertise as well offer some } \\
\text { practical support (e.g., meeting rooms). }\end{array}$ & 2 \\
\hline Greening Taupō & $\begin{array}{l}\text { Provide biodiversity plan and vision to } \\
\text { base authentic teaching and learning } \\
\text { programmes on. } \\
\text { Administer funds and employ and } \\
\text { manage the coordinator. }\end{array}$ & 2 \\
\hline $\begin{array}{l}\text { Tūwharetoa Māori } \\
\text { Trust Board }\end{array}$ & $\begin{array}{l}\text { Provide cultural learning opportunities } \\
\text { and facilitate interactions with } \\
\text { Tūwharetoa students and local } \\
\text { kaumātua.(elders). }\end{array}$ & 1 \\
\hline $\begin{array}{l}\text { Taupō District } \\
\text { Council }\end{array}$ & $\begin{array}{l}\text { Provide access and support for the } \\
\text { restoration of council-owned lands. }\end{array}$ & 2 \\
\hline $\begin{array}{l}\text { EO1 (Kindergarten: } \\
\text { approximately } 45 \\
\text { students) }\end{array}$ & $\begin{array}{l}\text { Develop affective domain for nature and } \\
\text { resilience through bush kindergarten. }\end{array}$ & 3 \\
\hline $\begin{array}{l}\text { EO2 (Kindergarten: } \\
\text { approximately } 55 \\
\text { students) }\end{array}$ & $\begin{array}{l}\text { Develop affective domain for nature and } \\
\text { resilience through bush kindergarten } \\
\text { and looking to grow nature in reserve } \\
\text { adjacent to kindergarten. }\end{array}$ & 3 \\
\hline $\begin{array}{l}\text { EO3 (Primary } \\
\text { school: } 447 \\
\text { students) }\end{array}$ & $\begin{array}{l}\text { Grow biodiversity/restoration knowledge, } \\
\text { skills, values and nature in their school } \\
\text { grounds. }\end{array}$ & 4 \\
\hline $\begin{array}{l}\text { EO4 (Primary: } 489 \\
\text { students) }\end{array}$ & $\begin{array}{l}\text { Grow biodiversity/restoration knowledge, } \\
\text { skills, values and nature in their school } \\
\text { grounds. }\end{array}$ & 3 \\
\hline $\begin{array}{l}\text { EO5 (Secondary } \\
\text { school: } 604 \\
\text { students) }\end{array}$ & $\begin{array}{l}\text { Grow biodiversity/restoration knowledge, } \\
\text { skills, values and nature at a local public } \\
\text { reserve. }\end{array}$ & 2 \\
\hline
\end{tabular}

and/or Board of Trustees of five educational organisations who had shown interest in involving their students in restoration activities prior to the program having been conceived.

\section{Data Collection}

For the duration of the Kids Greening Taupō pilot project, the lead author was privileged with a high level of access to the project, which included being officially invited to attend all affiliated meetings and events, copied in on the majority of emails between stakeholders, and given copies of relevant documentation. The methods used to generate data for this study were observation, interviews, and documentation analysis.

The researcher observed at a total of 91 meetings and events where data were gathered via general note-taking. Initially, an unstructured observational approach was undertaken whereby observations recorded were mainly of a descriptive nature, 
providing a foundation of familiarity with the program's stakeholders and education coordinator: who they were, their values, and how they contributed (or did not contribute) to the project. Over time, observations became more focused on the strategic elements, once the lead author had established a suitable understanding of the Kids Greening Taupō context and relevant literature. Thus, the initial inductive approach to data collection through observation slowly morphed to one that 'blended' the inductive with the deductive. Furthermore, the lead author's role at the meetings changed from purely that of an observer to a participant-observer as the stakeholders increasingly involved her in the project.

Approximately one year after the commencement of the pilot, all stakeholders were involved in semistructured interviews of up to 90 minutes' duration, either individually or in focus groups comprised of all representatives from each respective stakeholder organisation. Each interview was audio-recorded with permission and subsequently fully transcribed by the researcher. Transcripts were returned to all participants for verification and approval.

Throughout the duration of the pilot project, the researcher collected all Kids Greening Taupō documentation, aiming to select particular documents for analysis following the initial analysis of the observational field notes and interview transcripts. In this way, documentation analysis was used primarily to verify findings generated through observational and interview data. The documentation that was thematically analysed for this study included minutes from all meetings, some emails pertaining to specific partnership issues, and a selection of organisational documents, such as the program's strategic plan (Kids Greening Taupō, 2015).

\section{Analysis}

The initial thematic framework for this study emerged both inductively from the data collected via observations, and deductively, as guided by the analytical framework established through the theoretical perspectives derived from the literature reviewed. Following the development of the first set of thematic categories, the interview transcripts were read in full and coded, leading to the original framework being refined, aggregated and/or separated as appropriate. Mind mapping of the thematic categories was also undertaken, through which the researcher purposely looked for negative cases; and cross-checking of coding was carried out between the two authors to arrive at the final coding themes. Lastly, as highlighted previously, a selection of documents was analysed in order to further verify the thematic framework resulting from data gathered through the observations and interviews.

Ethical approval was obtained for the study, and it was made clear during informed consent processes that participant confidentiality in reporting data could not be guaranteed due to the small-scale nature of this study. Nevertheless, a pseudonym code (e.g., EO1, EO2) was used in place of the names of the educational organisations, teachers, and representatives from the community organisations, as this not only helped reduce the traceability of the data to some extent, but also enabled the frequency of the statements made by the participants to be tabulated.

\section{Findings}

This section begins with an overview of the structures and processes used to develop Kids Greening Taupō through a school community partnership and is followed by a description of the educational organisations' resultant environmental initiatives. Thereafter, based on stakeholder perspectives, findings relating to the opportunities provided by Kids Greening Taupō and some significant enablers and barriers to the 
developmental process of the program and its affiliated collaborative context are presented.

\section{The Development of Kids Greening Taupō}

The authentic local teaching and learning opportunity that Kids Greening Taupo was based on utilised the vision of Greening Taupō, a community group aiming to increase biodiversity in the town through the restoration of ecological corridors. The resultant environmental initiatives established by the educational organisations provided reallife learning experiences that could be incorporated into their respective curricula, while also enabling students, teachers, and their wider communities to positively contribute to their local context.

Initially, representatives from the partnering organisations and a representative from the secondary school formed a 'working group' that oversaw the early planning and implementation phases of the pilot project; this group also liaised with the kindergartens and schools to plan their environmental initiatives. Once funding was obtained for a salary, a part-time education coordinator was appointed and the working group morphed into the Strategic Leadership Group to guide program development based on an organisational perspective. A youth perspective to program development was sought through student representatives from each educational organisation who collectively formed a Student Leadership Team. Through the input of both these groups, the vision of Kids Greening Taupō was formulated as:

Kids Greening Taupō will enable young people to participate in real-life projects with opportunities to connect in a culturally responsive way to their local environment and community to increase biodiversity, student leadership and educational outcomes, shaping the future of our Place, now. (Kids Greening Taupō, 2015)

The partnering organisations provided educational organisations with expertise about ecological restoration and some necessary resources such as plants and spades, and the utilisation of council-owned reserve land for some of the environmental projects. In addition to this support, the working group envisioned a Take Action Fund, being money that educational organisations could apply for to put towards costs of their initiatives; however, the additional funding necessary for establishing this fund was unable to be acquired during the pilot.

A summary of the different projects developed by the educational organisations and some formative outcomes observed is presented next. This background is provided to assist readers to fully grasp the stakeholder perspectives around the development of Kids Greening Taupō through the school community partnership.

\section{Kindergartens (EO1 and EO2)}

Both participating kindergartens implemented a 'bush kindergarten' program and, when possible, incorporated students from the participating secondary school to help supervise as a means of fostering tuakana-teina relationships (big brother/sister, little brother/sister).

Initially, EO1's plan for bush kindergarten was to take children to a council-owned park every Tuesday morning for nature-based play. Parents would drop their children off and then, after a few hours, the teachers and children would walk back to kindergarten (approximately 1.5 kilometres). This plan was soon aborted after some parents opposed it because of their perceptions of dangers associated with strangers and dogs in the park, and walking alongside a busy residential street. As an alternative, teachers and parents agreed to a different location, being a small secluded block of recreational 
land set within an upmarket residential setting, and hired a bus for transportation. After approximately six months of bush kindergarten successfully being run from this location, the teachers were able to move the program back to the council-owned park as originally planned, albeit the bus continued to be used to transport the children back to kindergarten.

For EO2, its 4-year-olds participated in bush kindergarten on a fortnightly basis in a secluded nature setting on public land, requiring an approximate 20 -minute drive. At the same time, EO2 also set about restoring a council-owned reserve, adjacent to their kindergarten's boundary, providing all their children the regular opportunity to connect with natural surrounds. With the assistance of a local landscape architect, the children had input into the future design of this space, and plants and some labour was provided by council.

\section{Primary Schools (EO3 and EO4)}

EO3 adopted a whole-school project, creating He manu whenua (The bird land), a new pathway along the school boundary. As part of this project, students planted over 500 native plants with their families, and a plant propagation area and pump track were established. All students were involved in an inquiry about native flora and fauna, as well as each class undertaking their own inquiries that assisted other aspects of the project (e.g., predator tracking and trapping, cycle track design). Two students from each class formed a steering group, reporting back to their classes and organising 'Enviro Days' in conjunction with the school's enviro team to raise money for the initiative. At the end of the pilot, the Kids Greening Taupo education coordinator and the lead teachers reported that the whole-school approach was exceptionally hard work but well worth the effort in terms of the learning outcomes achieved (C, interview; T7, interview).

In contrast, EO4 utilised Kids Greening Taupō on a smaller scale, as it initially involved only Years 3 and 4 students (7- to 8-year-olds) in their Kaitiaki o te Whenua (Guardians of the Land) project that included a hikoi (trip) to eco-source flax seeds, native planting on the school grounds (including learning about propagation and traditional uses), a 'Green Day' (to celebrate learning and raise funds for more seedlings), and students sharing their learning with the wider school and Board of Trustees. Subsequently, a school-wide unit of learning, 'Eco-warriors', followed, addressing a range of environmentally important themes and culminating in displays in the hall that coincided with teacher-parent interviews. The inclusion of the 'nature zone' in the new school playground was inspired by the school's involvement in the program (T5, interview) and supported by local business.

\section{Secondary School (EO5)}

EO5's participation in Kids Greening Taupō was focused on developing a wildlife corridor within a council-owned park. This involved Years 9 and 10 students (13- to 14-yearolds) from one science class planting vegetation to provide year-round food for native species, and some initial attempts at pest tracking and trapping were made. Additionally, some extra-curricular involvement of the school's six Kids Greening Taupō leaders involved logo and website development, supporting the kindergarten initiatives, and helping to host a teacher professional development session at a local marae.

\section{Stakeholder Perspectives}

Findings from this study indicated that all lead teachers from the participating educational organisations and representatives from the partnering organisations (i.e., stakeholders) perceived there to be a number of opportunities generated through Kids Greening Taupō. Responses from 8 out of the 15 teachers interviewed indicated that 
involvement in the program gave them the impetus they needed to incorporate environmental education into curricula, while three other teachers believed Kids Greening Taupō was a 'vehicle' for enabling students to become active community members. In comparison, five of the seven representatives from the partnering organisations commented during their interviews about the importance they believed the program played in relation to connecting children and young people with their 'place'.

Three teachers also felt the program's high profile increased the integrity of their environmental initiatives and led to more support from the 'powers that be' (e.g., principals, council). As one teacher commented: 'It was that support that was about us being able to get this done. They [representatives from the partnering organisations] have the networks to council ... By having all those people behind us ... it's given it a better push' (T13, interview).

During the pilot, this support came mainly in the form of assistance from people, rather than money and tangible resources as originally planned through a proposed Take Action Fund. During the interviews, some teachers expressed their disappointment that this fund never eventuated; however, generally, the lack of funding did not prevent schools from participating in Kids Greening Taupō or progressing their projects. As explained by one teacher, the lack of monetary support encouraged their Parent Teacher Association, in conjunction with the school's administrators, to 'get much more creative' with regard to finding the funds necessary for their project(T8, interview).

All stakeholders were familiar with Aotearoa New Zealand's early childhood curriculum, Te Whāriki (MoE, 1996), and the school's compulsory curriculum (for Englishmedium schools - the New Zealand Curriculum (MoE, 2007) — and agreed that Kids Greening Taupō provided an excellent teaching and learning context well aligned to these documents. A representative from the Department of Conservation explained how she saw Kids Greening Taupō to be 'a gift bringing the curriculum to life. It enables teachers to teach the national curriculum in a real life, authentic, purposeful, meaningful way' (P3, interview). With regard to Te Whäriki, a kindergarten teacher remarked: 'Because Te Whāriki is very much about the wellbeing of the child and belonging in the community and holistic development, it [Kids Greening Taupō] really marries incredibly well' (T1, interview). Furthermore, 7 of the 15 teachers commented about the flexibility afforded by the non-prescriptive structure of the program, enabling them to incorporate it into their respective curricula in a way that best suited their kindergarten/school (e.g., whole-school approach, syndicate level, or extra-curricular project work). Nevertheless, although there was a collective perception that Kids Greening Taupō was well aligned to both national and local curricula, the data revealed different depths of stakeholder understanding and consensus about how the program and the resultant environmental initiatives could be further developed to more effectively deliver on the four underpinning components of the program, especially that of collaboration between schools and the continuous learning journey. As a Department of Conservation representative had put it:

\begin{abstract}
I think fundamentally, we [stakeholders] are all on the same page. The blue sky thinking that we did with our teachers very early on blew us away as they thought exactly like we did. But in terms of what that looks like, in terms of what do our schools do, need and how we can best support them ... I think there is a different depth of understanding. (P3, interview)
\end{abstract}

\title{
Stages of Program Development
}

In relation to the three broad stages of planning, implementing, and maintaining Kids Greening Taupō through its partnership structure, the data revealed a number of 
themes related to the processes occurring within each stage, as well as some developmental barriers. Findings from the data collected through observations and interviews reflected that early planning for Kids Greening Taupō predominantly focused on familiarising stakeholders (especially the teachers) about the Kepler program model and how it could be reconfigured to fit the Taupō context. This planning helped create a shared vision and effectively led to the development of the educational organisations' environmental initiatives being related to the authentic context of Greening Taupo's vision to restore biodiversity within the town. However, the findings also show 'gaps' in planning. For example, there was little evidence in the data indicating stakeholder reflection about certain strategic components like a coordinated funding strategy or an evaluative system for measuring and monitoring progress.

Following the planning stage, the observational data highlighted that the educational organisations and the working group expediently moved to implementing their environmental initiatives in order to coincide with the start of the school year. For some of the educational organisations, this meant that they had not thoroughly worked out how they would integrate their initiatives through cross-curricular learning programs. During the interviews, a number of teachers indicated that once the school year started, a lack of time and 'head-space' became major barriers, preventing them from further integrating their environmental initiatives more cohesively with their respective curricula. As one of the community representatives (who was a teacher formerly) explained:

Teachers are under such a huge amount of pressure with professional development, national standards, reporting, lunch time duty and kids that turn up with no lunch ... you get so immersed as a teacher in the day-to-day detail of just surviving, to take that big picture look and make those pedagogical connections is something you might do in the summer holidays but ... teachers on a daily basis do not have the headspace or time for such big picture thinking. (P3, interview)

A lack of structural capacity was also identified as a barrier, which impeded effective take-up and integration of Kids Greening Taupō as a learning context. Both secondary school teachers highlighted their school's 'siloed' disciplines and timetable as the most prevalent obstacle, whereas the teachers from one of the participating primary schools felt highly pressured by the large number of separate projects going on in their school. In this latter example, these teachers felt that involvement in the program became another thing they had to 'squeeze' in on top of everything else.

In the implementation stage, effective communication was perceived by stakeholders as a key process for developing Kids Greening Taupō. Some of the data reflected communication as being an enabling process at times during the course of the pilot. For example, as explained by one of the community representatives, 'When there was a problem [in the working group], we would just keep talking about it until everyone agreed' (P7, interview). On the other hand, the findings also indicated there were numerous times when inadequate communication between stakeholders resulted in uncertainties or assumptions being made about program development. As one teacher reflected, 'Because we [teachers] did not get the kahunas [Take Action Fund] and all those kinds of things, Mrs Cynical Pants here decided that the program was probably going to fizzle out anyways' (T9, interview).

Logistical organisation, of which communication plays an integral role, was found to be another crucial process in developing Kids Greening Taupō. All stakeholders commented in one way or another about the paramount need to plan well in advance. Such planning included working through matters like project management of the environmental initiatives according to the seasons, identifying meeting and event dates, 
obtaining equipment to enable students to undertake hands-on restoration work, and organising transportation and risk assessment documentation. As one teacher said:

I got the sense that it [the pilot] was evolving ... but as teachers, you need a termby-term structure so you can fit things in, and we would have done better justice to the job if we had known these are the meetings, and these are the things to get done by, and when the visits to various places were. (T6, interview)

Similarly, another teacher said that with more forward planning, she would have been in a much better position to use Kids Greening Taupō events as a 'springboard' for lesson planning (T7, interview). Furthermore, one of the kindergarten teachers highlighted that logistical planning should endeavour to ensure that the available support (e.g., funding, equipment, professional expertise) is shared among the participating educational organisations as fairly and equitably as possible (T15, interview).

There were few findings related to the maintenance of the program due to it being fairly new. However, within the data, there was a consensus among the stakeholders that if Kids Greening Taupō was to be sustained, participation must be kept interesting, fun and memorable' (P6, interview). In relation to the pilot project, a number of stakeholders perceived there had been too many meetings, many of which were overly long and formal. As succinctly put by one teacher, 'There was too much hui [meetings], not enough do-ey' (T6, interview). Aligning with this idea, both a teacher and a representative from council identified a need for more 'quick wins' so that the children and young people did not get dragged down by the red tape of bureaucratic planning and the long-term timeframe necessary for genuine restoration outcomes to be fully recognised (T12, interview; $\mathrm{P} 6$, interview).

\section{Discussion}

The purpose of this study was to first identify the structures established and processes undertaken by stakeholders to develop and implement Kids Greening Taupo through a school community partnership, including some of its formative outcomes. Second, stakeholder perspectives were sought in relation to evaluating this developmental process.

As a conservation education program, Kids Greening Taupō is placed within the environmental and education sectors. Broadly, partnership models addressing environmental issues have been increasingly used, as the issues tend to be multidisciplinary and therefore require cross-sectoral collaboration (Clarkson, 2015). In comparison, partnerships in the educational context have been used less frequently even though theory suggests that the socialisation and education of children is best achieved through cooperative action and support between schools, families and wider communities (Epstein, 1987). The development of more school community partnerships is likely if a 21stcentury approach to education, as espoused by the educational research community (Bolstad et al., 2012), becomes increasingly entrenched.

Because educational partnerships and their resultant education programs evolve within a unique context comprised of different organisations, people and places, there is no one 'recipe' of structures and processes that will ensure success. However, through the experiences of the Kids Greening Taupō pilot program and the affiliated research, a framework referred to as the Collaborative Community Education Model was identified (see Figure 1; DePetris, 2016). The aims of the model and the findings of this study are to provide guidance about the development of other similar programs based on participatory and action-based pedagogy through a partnership structure.

As shown in Figure 1, at the core of the Collaborative Community Education Model is a local issue or problem that is used by the participating educational organisations 


\section{Collaborative Community Education Model}

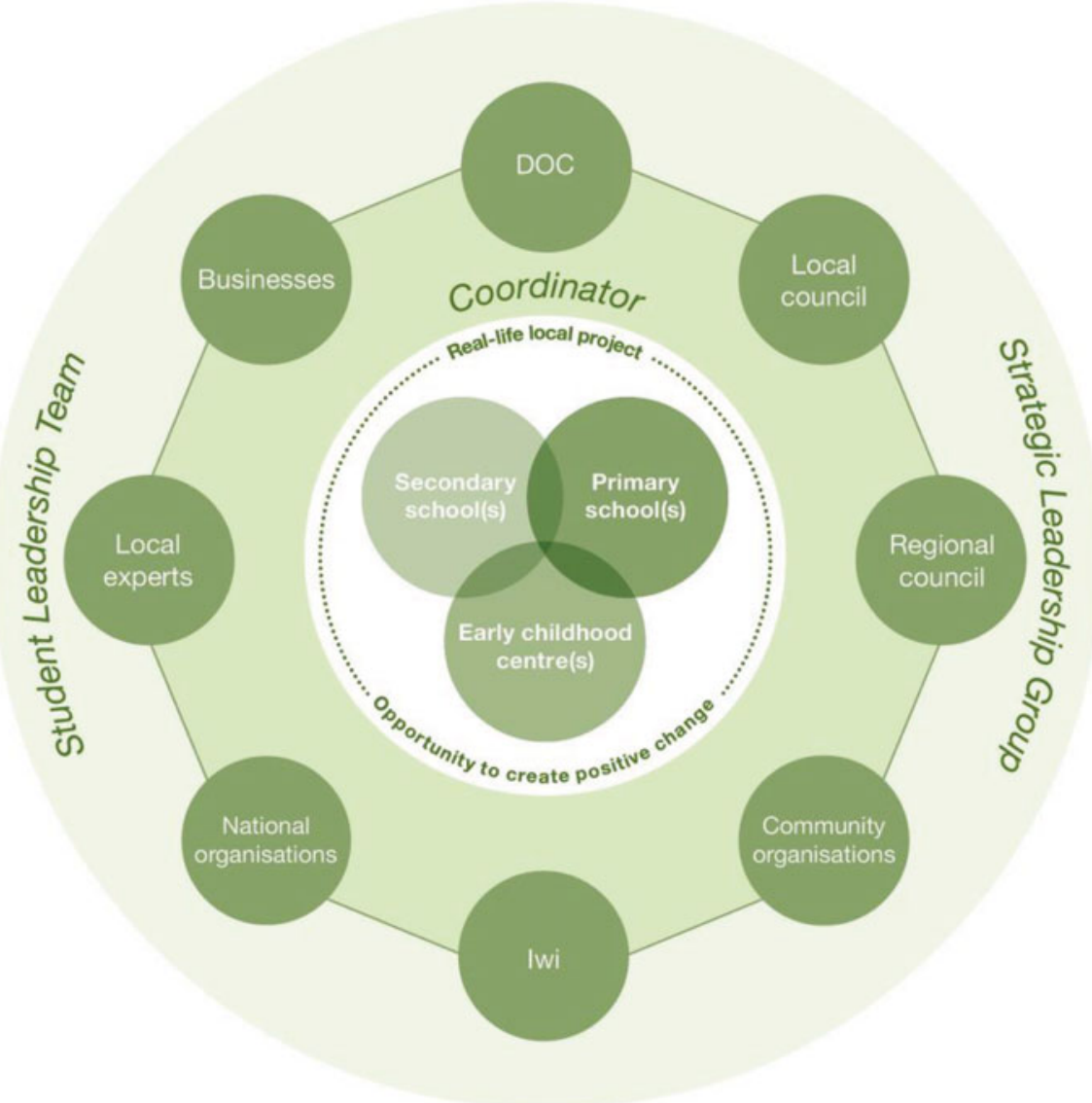

\section{Key strategic roles}

Programme strategy development and leadership by two important groups:

1. The Strategic Leadership Group - comprised of representatives from partnering organisations.
2. The Student Leadership Team - nominated students from participating schools.

The Coordinator role is essential to facilitate interactions between the schools and community partners to achieve the programme goals, as identified in the strategy.

Figure 1: (Colour online) The Collaborative Community Education Model. 
as an authentic teaching and learning opportunity. Supporting the education organisations is a network of community partners with organisational objectives that seek to resolve the subject issue. For this reason, these partners provide educational organisations with support and assistance as their involvement, via teachers, students and their respective wider communities, is likely to increase the number of people taking action to resolve the problem. An education coordinator or 'boundary-broker', as referred to by Monroe et al. (2016), plays a critical role in organising and facilitating the interaction between all stakeholders. The strategic direction of the program is overseen by a Student Leadership Team formed through the nomination of students from the participating educational organisations and a Strategic Leadership Group comprised of representatives from the partnering organisations.

Overall, the stakeholders interviewed for this study perceived that Kids Greening Taupo and the school community partnership through which it was developed offered both the participating educational organisations and community organisations many beneficial opportunities, and that there were educational, ecological, social and professional outcomes achieved during the 18-mpnth pilot program.

Findings related to the chronology of Kids Greening Taupō align with the literature about partnerships, such that three broad stages of program development with a number of processes or steps in each stage were identified.

Robust and thorough planning sets the foundation for an effective and sustainable partnership (Minkler et al., 2008). The importance of this stage should not be underestimated, as this thinking and work lays the foundation from which the collaborative program develops. The results of this study indicated that the planning led to the involvement of stakeholders who all saw value in partnering and were able to make worthwhile contributions towards achieving the program's goals. However, as the start of the school year approached, the focus of the stakeholders rapidly shifted from planning to implementation. Unfortunately, this left some important planning considerations unattended to. In hindsight, more time for planning should have been allocated.

Following the planning stage, stakeholders collectively develop action steps and delegate responsibilities as part of the implementation stage ( $\mathrm{MoE}, 2015)$. This stage tends to be characterised by 'hurdles' or challenges as unforeseen issues and/or dynamics tend to arise, although the number and magnitude of these challenges can be minimised by thorough planning (Thompson, 2002). In line with this, the development of Kids Greening Taupō during the implementation stage was characterised by change and busyness as an education coordinator was hired, a couple of the SLG representatives left their Kids Greening Taupō roles because of job transfers, and the school year got underway. Through the interviews with the stakeholders, effective communication, logistical organisation completed well in advance, and professional development opportunities for teachers in relation to biodiversity and restoration (including from both European and Māori perspectives) were all identified as being critically important to the success of the programme.

Lastly, as discussed with one of the community partners, it is often the case that determining what works and does not work in relation to strategy and operations for a program like Kids Greening Taupō can only be learned on a practical level over time (P2, interview). Therefore, full program potential is only likely to be reached if there is long-term commitment through organisational buy-in (Woodhouse, 2009). Additionally, some stakeholders expressed their belief that the sustainability of Kids Greening Taupō was highly dependent on the ongoing quality of the experiences for the participants; in other words, those that are enjoyable, interesting, and having positive outcomes over a relatively short-term timeframe. Therefore, an evaluative system providing an evidence trail of activities and outcomes in terms of both successes and 'learnings' is another key 
'ingredient' for an effective school community partnership as it can help facilitate a culture of sharing success and celebration (Sanders, 2001).

\section{Conclusion}

Through the experiences of Kids Greening Taupō, this study provides some guidance for developing community-based action opportunities for children and young people through a school-community partnership. This guidance is based on the insights and perspectives of Kids Greening Taupō's stakeholders involved in the 18-month pilot project. The findings demonstrate robust planning, ongoing communication, organisational buy-in, 'quick-wins', and evaluation as being critical components for developing effective school-community partnerships. Additionally, professional development related to key themes of the action opportunities offered through a partnership are important for increasing teachers' capabilities and confidence to deliver and embed these into their respective curricula. Emerging from this study was the Collaborative Community Education Model, a framework that may provide a starting point for others interested in initiating a new school community partnership or modifying an existing one. Broadly, a collaborative program in an environmental context unites educational organisations and community partners with a common purpose of taking action for the environment while simultaneously helping teachers to integrate associated learning programs within their respective curricula. Through the Collaborative Community Education Model, programs like Kids Greening Taupō can help improve community and environmental welfare through the distribution of resources and expertise from regional and national organisations to grass-roots efforts. In this way, children and young people are afforded authentic learning opportunities that simultaneously can enable them to contribute to making a positive difference today. How students experience the benefits of school community partnerships was not the focus of this study, and this would be an important area for future research.

Keywords: conservation education, biodivesity, collaboration, partnerships

\section{References}

Barza, L. (2013). School-business partnerships: The case of the UAE. Journal of Strategy and Management, 6, 180-189. https://doi.org/10.1108/17554251311322431

Bolstad, R. (2015). Schools collaborating with community and professional experts. Retrieved September 28, 2015, from http://www.nzcer.org.nz/research/ schools-collaborating-community-and-professional-experts

Bolstad, R., Gilbert, J., McDowall, S., Bull, A., Boyd, S., \& Hipkins, R. (2012). Supporting future-oriented learning \& teaching - A New Zealand perspective. New Zealand: Ministry of Education. Retrieved from http://www.educationcounts.govt.nz

Capra, F. (1994). Ecology and community. Retrieved September 16, 2015, from http: //www.ecoliteracy.org/article/ecology-and-community

Chapin, F.S., Mark, A.F., Mitchell, R.A., \& Dickinson, K.J.M. (2012). Design principles for social-ecological transformation toward sustainability: Lessons from New Zealand sense of place. Ecosphere, 3, Article No. 40. https://doi.org/10.1890/ES12-00009.1

Clarkson, B.D. (2015, August 24). The huge challenge of fighting pest and weeds. Nine to noon. Radio New Zealand. Retrieved from http://www.radionz.co.nz/national/ programmes/ninetonoon

Dator, J. (2014). Four images of the future. SET: Research Information for Teachers, 1, 61-63. Retrieved from http://www.nzcer.org.nz/mzcerpress/set/articles/ four-images-future 
Davies, D., \& Johnson, V. (1996). Crossing boundaries: An introduction. International Journal of Educational Research, 25, 3-7. https://doi.org/10.1016/0883-0355(96) 82037-4

Department of Conservation. (2011). National Education Strategy 2010-2030. Wellington, New Zealand. Retrieved from www.doc.govt.nz

DePetris, T. (2016). Kids Greening Taupō: Conservation education based on a collaborative community education model. University of Waikato, Hamilton, New Zealand. Retrieved from www.researchcommons.waikao.ac.nz/handle/10289/2222

Epstein, J. (1987). Toward a theory of family-school connections: Teacher practices and parent involvement. In K. Hurrelmann, F. Kaufmann, \& F. Losel (Eds.), Social intervention: Potential and constraints (pp. 121-136). New York, NY: De Gruyter.

Epstein, J., \& Sanders, M.G. (1998). What we learn from international studies of schoolfamily-community partnerships. Childhood Education, 74, 392-394.

Ernst, J. (2007). Factors associated with K-12 Teachers' use of environment-based education. The Journal of Environmental Education, 38, 15-32.

Falk, J.H., Dierking, L.D., Osborne, J., Wenger, M., Dawson, E., \& Wong, B. (2015). Analysing science education in the United Kingdom: Taking a system-wide approach. Science Education, 99, 145-173. https://doi.org/10.1002/sce.21140

Ferreira, M.M., Grueber, D., \& Yarema, S. (2012). A community partnership to facilitate urban elementary students' access to the outdoors. School Community Journal, 22, 49-64.

Gruenewald, D.A. (2003). Foundations of place: A multidisciplinary framework for place-conscious education. American Educational Research Journal, 40, 619-654.

Hands, C. (2005). It's who you know and what you know: The process of creating partnerships between schools and communities. School Community Journal, 15, 63-84.

Hill, A., \& Brown, M. (2014). Intersections between place, sustainability and transformative outdoor experiences. Journal of Adventure Education and Outdoor Learning, 14, 1-16. doi:10.1080/14729679.2014.918843

Hipkins, R., Cowie, B., Boyd, S., Keown, P., \& McGee, C. (2011). Curriculum implementation exploratory studies 2 (RMR-994). Wellington, New Zealand: Ministry of Education. Retrieved from https://www.educationcounts.govt.nz

Israel, B.A., Schulz, A.J., Parker, E.A., \& Becker, A.B. (1998). Review of communitybased research: Assessing partnership approaches to improve public health. Annual Review of Public Health, 19, 173-202. https://doi.org/10.1080/13576280110051055

Israel, B.A., Schulz, A.J., Parker, E.P., \& Becker, A.B. (2001). Community-based participatory research: Policy recommendations for promoting a partnership approach in health research. Education for Health: Change in Learning \& Practice (Taylor \& Francis Ltd), 14, 182-197. https://doi.org/10.1080/13576280110051055

Kids Greening Taupō. (2015). Kids Greening Taupō community restoration education programme [internal document]. Author.

Kids Restore the Kepler. (2016). Kids restore the Kepler. Retrieved May 13, 2016, from www.kidsrestorethekepler.co.nz

Margerum, R.D. (2008). A typology of collaboration efforts in environmental management. Environmental Management, 41, 487-500. https://doi.org/10.1007/ s00267-008-9067-9

McDowall, S. \& Whatman, J. (2016) Schools collaborating with experts in the community: All the school's a stage - Pakuranga Intermediate School. Wellington, New Zealand: 2016. Retrieved from www.nzcer.org.nz/reserach/publications/ all-schools-stage-schools-collaborating-experts-community 
McMillan, S.G., \& Binns, T. (2011). Environmental education and learning communities: The case of Kaikorai Stream, Dunedin, New Zealand. New Zealand Geographer, 67, 199-212. https://doi.org/10.1111/j.1745-7939.2011.01212.x

Ministry of Education. (1996). Te Whäriki: Early childhood curriculum. Wellington, New Zealand: Learning Media Limited.

Ministry of Education [MoE]. (2007). The New Zealand curriculum for English-medium teaching and learning in years 1-13. Wellington, New Zealand: Mediaworks.

Ministry of Education. (2015). Education for enterprise: Developing effective education for enterprise learning partnerships with the community. Retrieved October 19, 2015, from http://education-for-enterprise.tki.org.nz

Minkler, M., Vásquez, V.B., Tajik, M., \& Petersen, D. (2008). Promoting environmental justice through community-based participatory research: The role of community and partnership capacity. Health Education \& Behaviour, 35, 119-137. https://doi.org/ 10.1177/1090198106287692

Monroe, M.C., Ballard, H.L., Oxarart, A., Sturtevant, P.J.J., \& Evans, E.R. (2016). Agencies, educators, communities and wildfire: Partnerships to enhance environmental education for youth. Environmental Education Research, 22, 1098-1114. https:// doi.org/10.1080/13504622.2015.1057555

Orr, D.W. (1992). Ecological literacy: Education and the transition to a postmodern world. Albany, NY: State University of New York Press.

Sanders, M.G. (2001). The role of 'community' in comprehensive school, family, and community partnership programs. The Elementary School Journal, 102, 19-34.

Sanders, M.G., \& Lewis, K.C. (2005). Building bridges toward excellence: Community involvement in high schools. The High School Journal, 88, 1-9.

Smith, G.A. (2002). Place-based education. Phi Delta Kappan, 83, 584.

Statistics New Zealand. (2016). New Zealand population tables. Retrieved June 20, 2016, from www.stats.govt.nz

Sterling, S. (2001). Sustainable education: Re-visioning learning and change. Bristol, UK: J.W. Arrowsmith.

Thompson, J. (2002). Community education and neighbourhood renewal. Leicester and Cardiff, UK: National Institute of Adult Continuing Education.

Uzzell, D. (1999). Education for environmental action in the community: New roles and relationships. Cambridge Journal of Education, 29, 397-413.

Wei-Skillern, J., \& Silver, N. (2013). Four network principles for collaboration success. The Foundation Review, 5, 122-129. https://doi.org/10.4087/ FOUNDATIONREVIEW-D-12-00018.1

Woodhouse, D. (2009). Community partnerships. In SAGE key concepts series: Key concepts in community studies. London, UK: Sage UK. Retrieved from http://ezproxy.waikato.ac.nz/login?qurl=http\%3A\%2F\%2Fsearch.credoreference. com $\% 2$ Fcontent $\% 2$ Fentry $\% 2$ Fsageukkccom $\% 2$ Fcommunity_partnerships $\% 2 F 0$

\section{Author Biographies}

Thea DePetris has recently completed her Masters of Education from the University of Waikato, Hamilton New Zealand. As the topic for her thesis, Thea conducted an evaluation of the Kids Greening Taupō pilot project with the purpose of developing an understanding of the structures formed and processes undertaken to design and implement this collaborative community education programme. This article summises some of the findings that emerged from the study, which can be found in full from the University of Waikato's Research Commons. Presently, Thea is the 
Education Coordinator for Kids Greening Taupō, and in her spare time contemplates further academic research opportunities.

Chris Eames is a lecturer in environmental and sustainability education (EE) at the University of Waikato in Hamilton, New Zealand. He works with preservice and inservice teachers, and with many postgraduate students, with a particular focus on education practice. He also advocates at national level for environmental and sustainability education (ESE) as a National Executive member for the New Zealand Association for Environmental Education, and works at a local level to promote ESE and to protect and restore the natural environments in his country. He is Associate Editor of the Australian Journal of Environmental Education. 